\title{
25 The Internationalization of SMEs in Malta: a critical assessment in the context of five European island regions Godfrey Baldacchino
}

\section{Introduction}

Malta is the official name of a resource-poor, semi-desert limestone archipelago consisting of two main inhabited islands (Malta and Gozo), with a total surface area of just 312 square $\mathrm{km}$ (126 square miles), located some 60 miles off the southern tip of Sicily. A population of 400000 makes the Maltese Islands the second most densely populated state in the world, after Singapore. Given its geostrategic location at the crossroads of the Mediterranean, plus its excellent sheltered harbours, the islands have been targets of covetous rulers throughout its history, to the extent that its islanders learnt to manage and even appreciate the benefits of a 'fortress economy' which boomed in wartime and slumped in peace (Zammit, 1994: 12; Busuttil, 1973: 1). The few indigenous manufacturing industries - such as salt harvesting (during Roman Times) and cotton growing and weaving (during early British rule) - which sought to thrive independently from the military operations, were typically short-lived affairs. The radical revision of Britain's global military role after the Suez Crisis of 1956 meant that 'Malta as fortress' was suddenly expendable, and that a serious economic restructuring would be necessary to develop alternative employment opportunities for the distraught islanders. It was in 1959 that the first of six development plans was ushered in (Baldacchino, 1998a); and Malta looked at exportoriented manufacturing fuelled by foreign investment and technology (Sklair, 1993: 1) as a viable economic strategy (Baldacchino, 1988). Until then, it would be fair to say that Malta's only significant indigenous manufacturing facility was its brewery: a condition shared by many small island jurisdictions. Employment opportunities have been largely in services, private (trade and tourism) and public (public service and public administration).

To support infant industries, successive governments created or maintained tariff barriers. A sober assessment of Malta's manufacturing capacity was well borne out by the avis (opinion) produced in June 1993 by the European Commission with respect to Malta's bid for EU membership:

Malta is a small economy, in which the great majority (more than 75 per cent) of its industrial companies employs fewer than five people. Of the 2,300 companies registered, only 61, less than 3 per cent, employ more than 100 staff and only 12 more than 300. (European Commission, 1993; Coopers \& Lybrand Europe, 1991, Appendix A-1)

Of the latter, only four were locally owned; and two of the four were heavily subsidized public companies. Moreover:

The vast majority of the smaller companies is engaged in sectors such as construction, machinery repairs, food and furniture and primarily targets the domestic market. These companies 
account for more than 70 per cent of industrial employment on the islands: their productivity is very low and their wages generally poor. In most sectors, they are sheltered from foreign competition by protective trade legislation and by extremely stringent tariff and non-tariff barriers. (European Commission, 1993; Coopers \& Lybrand Europe, 1991: 21)

All protectionist arrangements have now been dismantled in the run-up to EU accession, secured on 1 May 2004.

The above presents a historical appetizer to the challenges facing viable enterprise in Malta, a small sovereign nation which only secured political independence in 1964, after centuries of military colonialism during which time hardly any indigenous manufacturing capacity - except ship building and ship repair related to the war effort - was entertained.

\section{The argument}

This chapter will document the specific challenges that affect the internationalization of small-scale enterprises based on a small island jurisdiction. Dealing with small, discrete numbers; experiencing economic booms and busts; spawning companies which wield significant leverage by virtue of being modestly large; not to mention the structuring difficulties of operating viable manufacturing activities ... all these are issues which are not unique to Malta but are faced by other small island jurisdictions, since they are economic consequences of smallness and insularity. Thus, in this chapter, the analysis of the Malta situation will proceed from the perspective and vantage point of 'comparative island studies' (for example, Biagini and Hoyle, 1999; Baldacchino, 2004); drawing on recent fieldwork on the challenges facing small businesses from a number of different European island regions. The chapter argues that the successful internationalization of locally owned firms benefits handsomely from a thorough, qualitative analysis of successfully internationalized firms, scrutinized from a comparative perspective. It concludes with some learning nuggets, listing features that are deemed pertinent to successful SME internationalization in the small island scenario.

\section{Theoretical background: small firms in small islands}

Small-scale enterprises are recognized the world over as crucial to sustainable economic development (for example, Liedholm and Mead, 1999; Jones and Tilley, 2003); and more so in small economies than large ones where they easily command an even larger proportion of firms in business (for example, Granovetter, 1984; McDonald, 1999; Wignaraja and O'Neil, 1999). Small businesses gather resources to produce goods and services, create jobs, motivate those associated with them to higher levels, decrease dependency on government, facilitate the integration of ethnic minorities, and support an economic development path that is considerably less expensive and often more sustainable than the massive influx of capital, advanced technology and highly specialized personnel needed for developing large businesses (McClelland, 1987: 232; Boissevain et al., 1990). Their critical importance to the Maltese economy has been highlighted in a few seminal articles (such as Briguglio, 1998; Boissevain, 1991; Mizzi, 1996). That policy makers seek to introduce a fiscal, human resource and general policy regime that is supportive of and conducive to successful SME establishment and growth should therefore come as no surprise. 
Much of this effort to support small firms is based on and confined to national or regional markets. After all, the regulatory environment, educational and human resource development policies, taxation regimes and other features deemed to have an impact on the number and quality of entrepreneurs, innovators and small firms are typically within the control and decision-making power of national governments, with features of shared rule in the case of members of regional fora (as in the case of environmental, labour relations and occupational health and safety regulations within the European Union). The comparative, cross-national examination of small firm 'success', however defined, is a more demanding undertaking, requiring a careful methodology to control for various national, fiscal, product area and enterprise-specific variables. ${ }^{1}$ A largely neglected aspect of this comparative approach puts island populations into the same analytic category. Conceptual research on small firms in small islands has raised awareness of insightful common patterns at both the micro level (such as entrepreneurial behaviour and recruitment tactics) and macro level (such as branding strategies) (for example, Baldacchino, 1999a, 1999b, 2002; Fairbairn, 1988b).

\section{A methodology for defining success}

The NISSOS Project ${ }^{2}$ has been seeking to understand the conditions behind the success of exceptional small firms in Europe by using an inductive, comparative methodology. The project has determined a tough and stringent set of criteria for defining success; sought out firms which match those criteria; and then delved into detail to understand the particular ensemble of characteristics of these firms, teasing out what appears to be idiosyncratic, and then re-examining these features in the context of general lessons for successful SME manufacturing development. The project's special interest and focus lies firstly in island territories: tracts of land surrounded by water (at both high and low tide), conceived as locations where successful economic activity is arguably hampered by such features as isolation, peripherality and diseconomies of scale. The focus has, secondly, also been explicitly on manufacturing firms: discrete economic units whose main product is not a service, but is tangible, requires some kind of material input and whose site of consumption can be distinct from that of its production. Manufacturing remains important because it is recognized as typically a stronger provider of permanent and well-paying employment, with large multiplier effects (including service jobs and skill development) to the local economy (for example Seers, 1982: 74; Baldacchino, 1998b: 269).

The definition of success adopted by the NISSOS partners has been deliberately set at a most challenging level. To qualify, island-based manufacturing firms had to be locally (that is, island)-owned; primarily export (that is, off-island)-oriented, and had to have been so for (at least) the previous three years; having fewer than 50 employees; and utilizing adapted or locally developed (and not just imported and/or adopted) technology. The choice of these criteria was a direct response to the tenets of conventional wisdom as they apply to (especially small) island territories. According to such 'common sense', small islands are deficit locations: they are prone to suffer from the absence of returns to scale in both public goods and private service provision, both being generally constrained by indivisibilities (Alesina and Spolaore, 1997; Barro and Sala-I-Martin, 1995). Small island economies are also claimed to be less likely to be able to diversify, making them vulnerable to economic shocks (Briguglio, 1995; Commonwealth Secretariat, 1997). Public servants operate under regular conflicts of interest, and are under considerable pressure 
to honour obligations and curry favour (Farrugia, 1993), while a limited pool of human resources may lead to the recruitment and promotion of the mediocre (Streeten, 1993). Small islands are thought to be structurally cheated of markets, economies of scale and institutional 'thickness' (Amin and Thrift, 1994: 14-15). Kaminarides et al. (1989) list no fewer than 19 different deficits that are meant to apply to small island economies. These and similar ideas are now well enshrined in Article 299.2 (ex-Article 227) of the Treaty of Maastricht (1997) as applying to the European Union's outermost (or so called ultraperipheral) regions. This Article claims that: 'remoteness, insularity, small size, difficult topography and climate [as well as] economic dependence on a few products' are structural features whose permanence and combination severely restrain (especially small) island development.

The NISSOS definition was conceived with a view to challenging such received wisdom, in support of growing empirical evidence to the contrary (Easterly and Kraay, 2000; Armstrong and Read, 2002, 2003; Baldacchino, 2005a). Furthermore, in raising the bar as high as possible, and in excluding many thriving small firms (especially service firms) from its remit in the process, only the truly exceptional (as against the humdrum representative) were being scouted by NISSOS. Moreover, the size of the database was rendered manageable and avoided any resort to sampling.

In this way, and in spite of some initial scepticism, a total population of 144 firms which matched the stringent criteria was identified in the five partner island territories.

\section{Results}

The lessons from NISSOS are still being evaluated, and other academic papers are exploring other implications arising from the research results (for example, Baldacchino, 2005b, 2005c). Meanwhile, five training manuals (one for each island region involved in the project, including Baldacchino and Vella Bonnici, 2005) as well as a multilingual CDROM are being produced as part of the project's deliverables. This chapter, pitched at a primarily international audience, invites readers to consider critically the quantity and quality of Malta-based successful firms, in the context of the NISSOS data and research template, and of the lessons learnt about SMEs generally from this research project.

\section{Number of firms}

One stark implication of the database is that Malta scores somewhat poorly in terms of its number of successful firms. The ratio of successful firms in Malta (as defined) in relation to local population is by far the lowest within the five-island sample (see Table 25.1); and this in spite of Malta having by far the largest population base of the five-island partnership. Unless this statistic is the outcome of underrepresentation of actual firms, Malta appears to suffer from a relative dearth of successful, small, export-oriented, manufacturing businesses.

The reasons for this shortfall could be varied and complex. However, a few explanations suggest themselves readily.

First of all, a relatively large population size permits some manufacturing firms to be set up with an exclusively local market orientation. Thus, a larger population base, especially on a fairly unified land mass (as in the case of Malta, followed by Iceland) increasingly means a potential domestic market for manufactured products, avoiding the obligation to export, and its associated hassles, costs and problems. In contrast, the smallest jurisdictions 
Table 25.1 Island territories, geographic, demographic \& economic details

\begin{tabular}{|c|c|c|c|c|c|c|c|}
\hline $\begin{array}{l}\text { Island } \\
\text { Territory }\end{array}$ & $\begin{array}{l}\text { Population } \\
\quad(000 \mathrm{~s})\end{array}$ & $\begin{array}{l}\text { Land area } \\
\text { (Sq. km.) }\end{array}$ & $\begin{array}{c}\text { No. of } \\
\text { islands } \\
\text { (populated) }\end{array}$ & Jurisdiction & $\begin{array}{l}\text { Successful } \\
\text { No. of } \\
\text { Successful } \\
\text { Firms }\end{array}$ & $\begin{array}{c}\text { Firms per } \\
10000 \\
\text { population }\end{array}$ & $\begin{array}{c}\text { Their } \\
\text { mean } \\
\text { workforce }\end{array}$ \\
\hline Iceland (IS) & 290 & 103,000 & 4 & Sovereign State & 42 & 1.5 & 26 \\
\hline $\begin{array}{l}\text { Maltese } \\
\text { Islands (MT) }\end{array}$ & 400 & 316 & 3 & Sovereign State & 33 & 0.8 & 22.5 \\
\hline Total & & & & & 144 & & \\
\hline
\end{tabular}

Source: NISSOS Project (2004). 


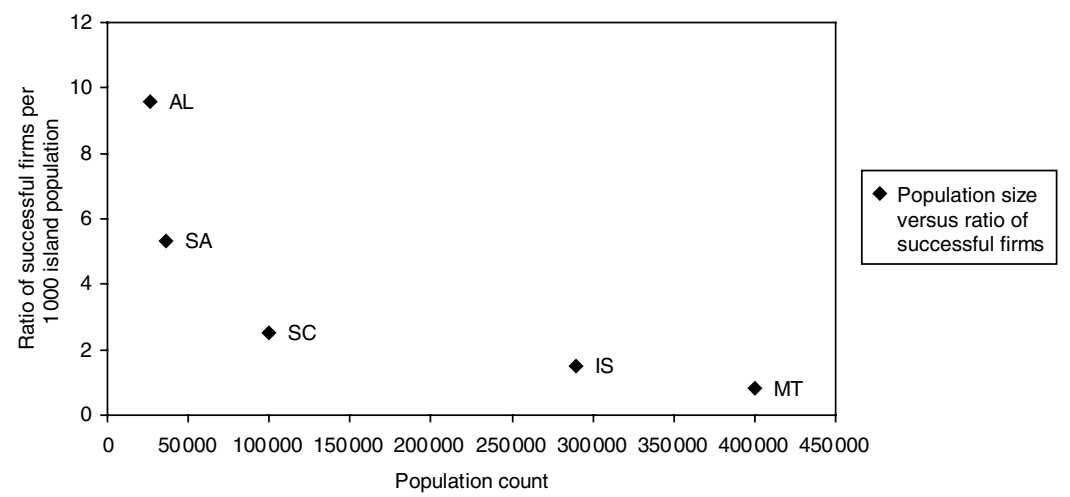

Source: NISSOS Project, (2004).

\section{Figure 25.1 Population size versus ratio of successful firms}

in the database, the island regions of Aland and Saaremaa, have such a small domestic population base that most manufacturing operations must consider export activity for sheer survival. The smallest economies are therefore more strongly in the throes of an 'export or perish' orientation (for example, Brookfield, 1987), imposing stronger obligations on such economies to spawn regionally or internationally competitive forms. The relationship between small population base and SME manufacturing export density on the basis of NISSOS data is statistically significant and clearly visible from Figure 25.1.

Secondly, the ability to export off-island to a territory which is part of the same political jurisdiction, speaks the same language and/or which is sympathetic to the island region facilitates the export transaction. In this sense, it is the sovereign islands of Malta and Iceland which lose out; while the Scottish Isles, Saaremaa and Åland can all benefit from a positive association with mainland Scotland/UK, mainland Estonia and Sweden/Finland, respectively. Sovereignty can thus be seen as a handicap to off-island trade; it is only by virtue of bilateral or multilateral regional trade agreements that this handicap can be minimized, but probably never totally eliminated.

Thirdly, sovereignty also exercises an opposing, positive influence on legislative capacity, however. Having the jurisdictional power to pass laws and regulations, along with the capacity to run and operate one's own shipping and air transport networks, facilitates manufacturing exports. The number of successful firms in Malta and Iceland would have arguably been even lower had not these island regions also been sovereign states in a position to deploy their own legislative powers as well as national airlines (Air Malta, Icelandair) and shipping companies (Sea Malta, Samskip and Eimskip) to support indigenous manufacturing export efforts. In contrast, the Scottish Islands, with their jurisdiction shared by no fewer than six local authorities, half of whom share responsibility over both island and mainland regions, find themselves politically starved of a coherent governance structure that might help them export more and better; though a ferry service under public ownership, Caledonian MacBrayne, is a subsidized monopoly, and this somewhat facilitates trade between the islands and the mainland (Royle, 2001: 111-13). Åland, being a unique, autonomous but non-sovereign jurisdiction, has some limited ability to oblige its own political machinery to render economic service (with a strong bias 
in favour of its own impressive shipping fleet register); while Saaremaa is a county/local authority and thus enjoys only administrative capability.

\section{Type of firms}

A different assessment can be carried out when one takes a more detailed look at the types of products that these 144 successful manufacturing firms are producing. The products come in two main varieties. On one hand, one finds a clutch of low-tech, labour-intensive, mainly craft or agrobased products deliberately seeking to plug into the tourism market and seeking to associate themselves with their particular island brand or lure. It is the tourist who would incur any transport costs here. On the other hand, one finds high-tech, high-value added, knowledge-intensive products which are either light in weight/small in volume or else are 'virtual' products which can be 'exported' with considerable ease, such as downloaded from an Internet site. In both cases, costs of transportation are minimal or non-existent. The products are collated by island territory and economic sub-sector below (see Table 25.2).

Even the empty cells in the table are suggestive. Saaremaa, operating in an economic environment still undergoing fledgling liberalization after many years under state totalitarianism, has very few small, locally-owned, high-tech, export-oriented firms. In spite of North Sea Oil and Gas, the Scottish Isles have not seen this industry develop any notable upstream or downstream local manufacturing activity amongst its SMEs. Iceland, with its exhorbitant labour costs, finds itself uncompetitive in labour-intensive products. Its tourist industry, although up-market, boasts 'only' some 300000 visitors per year.

Instead, Iceland has done well in spawning a clutch of diverse, successful, small firms from its major export industry (fishing), as well from a burgeoning information technology sector. The association with wellness and fitness supports the sale of some of its health products, based on fishery derivatives. A similar and deliberate association between wood and Saaremaa, the renowned Mediterranean diet (wine, olive oil, tomatoes) and Malta as well as (of course!) whiskey and Scotland, facilitates the export of such specific products as long as they maintain the highest levels of quality: this strategy fends off similar competing products from cheaper locations. Malta's decorative glassblowing industry is an interesting example of an 'invented tradition': a labour-intensive operation that has been marketed as 'traditional' when the local industry owes its birth to two English partners as recently as $1968 .{ }^{3}$ In such cases, as with the modern invention of the Scottish kilt and tartan (Trevor-Roper, 1983), even the tradition has been (ingeniously) manufactured. In the Malta case, it has also been successfully indigenized.

There is also evidence of some of the firm clustering that is today being hailed as a key driver of competitive industry: by creating conditions suitable for the development of collective efficiency, clustering enhances the competitive advantage of firms and makes it easier for them to respond to both opportunities and crises (for example, Porter, 1990). Clustering in small island locations, however, appears to warrant some specific observations. Geographically, small firms on small islands are indeed located on relatively compact zones; once organized, they can also develop a sense of cooperative competition or 'co-opetition' (for example, Golden, 1994), especially in developing a strong island brand overseas, as has been done effectively by the Shetland Lady trademark in the Shetland Islands; ${ }^{4}$ thirdly, they set up and cultivate crucial off-island links in order to secure markets, source new ideas, approach new clients and exploit opportunities 
Table 25.2 Products of successful firms, by island and economic sub-sector (number of firms in brackets)

\begin{tabular}{|c|c|c|c|}
\hline Island territory & Number of firms & Natural craft & Natural agro \\
\hline Åland Islands & 25 & $\begin{array}{l}\text { wood panels } \\
\text { Furniture } \\
\text { sheet-metal (9) }\end{array}$ & $\begin{array}{l}\text { meat processing } \\
\text { fish processing } \\
\text { sour apples ( } 7)\end{array}$ \\
\hline Iceland & 42 & & $\begin{array}{l}\text { cod/shark liver oil } \\
\text { cattle food } \\
\text { candy } \\
\text { poultry processing } \\
\text { fish processing (20) }\end{array}$ \\
\hline Maltese Islands & 33 & $\begin{array}{l}\text { decorative glass/lace } \\
\text { gold/silver filigree } \\
\text { furniture (6) }\end{array}$ & $\begin{array}{l}\text { olive oil } \\
\text { wine/sausages } \\
\text { sun-dried tomatoes } \\
\text { liqueurs (6) }\end{array}$ \\
\hline Saaremaa & 19 & $\begin{array}{l}\text { lime/agar/limestone } \\
\text { wooden houses } \\
\text { wooden boats }(8)\end{array}$ & $\begin{array}{l}\text { fish processing } \\
\text { berry processing } \\
\text { meat processing } \\
\text { fur products }(7)\end{array}$ \\
\hline Scottish Isles & 25 & $\begin{array}{l}\text { stone } \\
\text { woollen knits/fabrics } \\
\text { jewelry/furniture } \\
\text { pottery/drums (12) }\end{array}$ & $\begin{array}{l}\text { preserves } \\
\text { smoked salmon } \\
\text { whisky } \\
\text { beer ( } 7)\end{array}$ \\
\hline
\end{tabular}

Source: NISSOS (2004).

for professional development; fourthly, especially in knowledge-driven and technologyintensive industries, key links are established with such local institutions as universities and technical colleges, business incubators and technology centres. Such institutions would be relatively few and far between in small islands, but they are even rarer in small islands which are not jurisdictions. Thus, Iceland boasts three universities ${ }^{5}$ and a Technological Institute. ${ }^{6}$ In Malta's case, these would be the University of Malta, the Malta College of Arts, Science and Technology and the Business Incubation Centre run by Malta Enterprise. ${ }^{7}$ Meanwhile, at the other end of the scale spectrum, Saaremaa and Åland can each boast of one small technical college/polytechnic campus, ${ }^{8}$ while various Scottish Isles are served by some 33 satellite learning centres of the UHI Millennium Institute. ${ }^{9}$ Thus, those institutions which $d o$ exist in such locations have an enormous responsibility towards supporting local research and development efforts as well as facilitating the technical and professional formation of recruitable human resources. Furthermore, unlike the postulates of economic geography associated with clustering, successful small manufacturing firms on small islands do not initially become competitive on the basis of domestic competition, but must prove themselves from inception in international markets.

A further novelty associated with successful manufacturing firms in small islands is the juxtaposition of the actual production of the commodity with a service experience. 


\begin{tabular}{ll}
\hline Chemical / plastic & IT / Hi-tech/engineering \\
\hline sausage skins & purifier units \\
air cleaning systems & welding/electrical systems \\
plastic printing (5) & IT/software (4) \\
sulphur-resistant pipes & artificial intelligence games \\
plastic tubs/fishing nets & anti-virus software \\
fibreglass boats & electrical equipment \\
fish scales (9) & fish industry equipment \\
& digital EEGs (13) \\
plastic pipes/cables & IT packages \\
paints/detergents & software support \\
labels/packaging & solar panels (6) \\
injection moulding (15) & \\
rubber products (2) & aluminum boats (2) \\
& \\
toiletries/soaps (2) & \\
& \\
& electrical instruments \\
& flexible circuits \\
& observation devices \\
\end{tabular}

Cashing in on their attraction as targets of a 'tourist gaze' (after Urry, 1990), the act of manufacturing a specific product associated with a particular island is transformed into an item of interest and a novel experience to visitors. A factory is thus metamorphosed, without much effort, into a museum, not just a location for the production of souvenirs but also one of consumption where being there and seeing the product being made is itself memorable. This feature is being used to good effect by glassblowers and vintners in Malta, by whiskey distilleries in Scotland, and finds parallels in other island locations (for example, Baldacchino, 2002).

\section{Island location of firms}

Although not always articulated explicitly, references to an enviable 'quality of life' on a small island can be traced to all the successful island entrepreneurs in the NISSOS database. This feature might well include a well-bonded, flexibly-specialist and loyal workteam (Bennell and Oxenham, 1983), safe places to raise children, having strong family structures and boasting other social networks based on mutual knowledge and familiarity (Boissevain, 1974; Srebrnik, 2000), and other significant and long standing 'social capital' supports which promote unitarism (Baldacchino, 2005c). The island effect is not only significant in extending and packaging the 'island lure' to potential clients (e.g. Baum et al., 2000: Fairbairn, 1988a); it also attracts potential entrepreneurs, some of whom were 
born and bred off-island or else were born on the island but had drifted away in search of adventure, education and/or employment before being enticed back.

\section{Manufacturing enterprise in Malta: a harsh assessment}

In Malta, as with other European island regions, small firms are by far the most numerous economic units (for example, Granovetter, 1984). Yet, in Malta, as with other European island regions, the number of successfully internationalized small manufacturing firms is a very small fraction: just 0.8 per cent. ${ }^{10}$

The research advantage that a small island region provides is that comprehensive firm data are usually more readily available; more so in the case of a jurisdiction with an obligation to compile and maintain accurate statistics. The overall map of commercial firms in Malta in December 2004 reveals 23868 units, of which 88.6 per cent (21148) employ up to four persons. Of these, some 13000 involve self-employed, sole proprietors (see Table 25.3).

Malta ranks with Mauritius, Fiji and Singapore as one of the world's few island economies with a relatively strong manufacturing base (Baldacchino, 1998b: 271). About 16 per cent of Malta's employees still worked in private sector manufacturing in 2004, with another 4 per cent engaged in enterprises (like Malta Shipyards) where the state still retains total or majority control. This is a fortuitous outcome of a combination of factors, notable amongst which has been the long existence (for at least 450 years, and still counting) of a naval shipyard (which nurtured industrial skills and culture); a geographical location only 60 miles $(100 \mathrm{~km})$ from the European mainland; and a stable democratic polity which attracted a steady flow of foreign direct investment from the late 1950s (Vella, 1994). Still, there are downsides to such export oriented industrialization by invitation. Much FDI chose Malta also because of heavy subsidies, positively discriminatory legislation (such as concessionary access) and cheap wages: all three attractions have now been largely lost because of the obligations towards the European single market and the opening up of other, much cheaper, production locations. Moreover, a hoped-for 'trickle effect' of technological transfer remains largely illusory. The indigenous Maltese private economy is dominated by (a) a merchant class engaging in wholesale and retail trade, which makes its profits simply by transposing goods; (b) a construction industry which thrives thanks to the (so far) ready availability of globigerina limestone, its raw material; (c) a largely fragmented professional and personal service class often offering one-person services, ranging from legal advice to bus driving to hairdressing. Local manufacturers are wary and highly suspicious of overtures for cooperation with would-be local competitors; as a result, they continue to forgo specialization and to spend too much of their capital in excess capacity. Only 76 manufacturing firms employ more than 50 employees; and only eight employ more than 500; today, these are all largely internationalized and, barring a handful, would be non-Maltese-owned. By far the largest manufacturing concern in Malta is the branch of the semiconductor multinational S-T Microelectronics, with close to 2000 employees. Its future remains uncertain; it has threatened to relocate on a number of occasions (Zammit and Mintoff Bland, 1992: 17).

\section{A more sobering assessment}

The scenario, however, is not only one of doom and gloom: there exist a few but notable examples of successful, locally owned and internationalized, small-scale manufacturing operations from small islands, including Malta. These SMEs may not operate as parts of 
large knowledge clusters, but they have deployed their 'entrepreneurial innovation' skills ${ }^{11}$ by identifying what they can do best: promote quality (often branded) products for selective overseas up-markets, and luring innovators or clients from overseas in the process. Theirs is a message and a narrative of hope, demonstrating how, in spite of the heavy baggage of allegedly insurmountable constraints, the tyranny of geography can be overcome. Their stories deserve being showcased as 'best practices' that can be studied by other firms on the same or similar island territories. Such best practices may also, in turn, inform the training, education and professional development of business students, apprentices and/or actual or potential entrepreneurs from the same and other small island jurisdictions.

\section{Ten lessons from research findings}

What have been the main lessons learnt from the showcased successful firms? What transferable knowledge can be gleaned from case studies of enterprises which are clearly exceptional rather than representative? A set of ten, distinct yet interrelated, lessons suggest themselves from the research material.

\section{The nature and origins of entrepreneurship}

On small islands, returning emigrants or incoming settlers with skills and experience abroad are crucial in boosting the stock of entrepreneurs in the home country and in being able to tap overseas contacts and markets. Entrepreneurship also appears to be a somewhat gradual, incremental and summative set of experiences and learning, partly from formal schooling but also from conventional employment and incidental learning. Unemployment can be a trigger; but so can be a casual encounter with a potential buyer, or a chance discovery. The entrepreneur then weans himself away from employment into self-employment: there is no dramatic bursting on the scene. Growth is slow, measured, tentative . . . investments are often as low as possible, guaranteeing that control remains firmly in the hands of the founder/ideator.

\section{The nature of the material product}

An easy way to start a successful small business on a small island is to develop naturally available raw materials (wood, glass, wool, stone and so on) into products that are geared towards a tourist market, but issues of quality, packaging, display and consistency soon emerge, enabling some sifting and thinning of the myriad producers. A consistent island brand, a mechanism for certifying the genuineness of local products, some concerted effort by local producers to cooperate in sourcing off-island markets (co-petition), rather then engage in all too common internecine conflict and rivalry, are important markers on the road to firm and industry success. The use of the factory as a 'looked-at' site is also helpful, combining production and consumption, and thus, hopefully, boosting sales.

\section{The nature of the virtual product}

Software and virtual products (like products sold over the web and software) offer obvious advantages to all producers, avoiding transport and insurance costs; but island-based producers reap the largest potential advantage, since they suffer most from transport handicaps. Developing a product (and a market) from scratch helps immensely. The 'exotic' link with an island can help in relationship marketing, but not too close a branding with the island is preferred. 
Table 25.3 Employment levels by economic sub-sectors in Malta, end December 2004

\begin{tabular}{|c|c|c|c|c|c|c|c|}
\hline \multicolumn{2}{|c|}{ Industry sector } & \multirow{2}{*}{$\frac{1-4}{1389}$} & \multirow{2}{*}{$\begin{array}{r}5-9 \\
10\end{array}$} & \multirow{2}{*}{$\frac{10-19}{12}$} & \multirow{2}{*}{$\frac{20-29}{1}$} & \multirow{2}{*}{$\frac{30-49}{3}$} & \multirow{2}{*}{$\frac{50-74}{0}$} \\
\hline 01 & Agriculture & & & & & & \\
\hline 04 & Fishing & 368 & 1 & 2 & 0 & 1 & 0 \\
\hline 13 & Oil Drilling & 92 & 1 & 1 & 0 & 0 & 0 \\
\hline 14 & $\begin{array}{l}\text { Stone Quarrying and } \\
\text { Clay pits }\end{array}$ & 55 & 6 & 5 & 1 & 1 & 0 \\
\hline 19 & Non metallic quarrying & 1 & 0 & 0 & 0 & 0 & 0 \\
\hline 20 & $\begin{array}{l}\text { Food Manufacturing } \\
\text { Industries }\end{array}$ & 552 & 48 & 21 & 7 & 11 & 4 \\
\hline 21 & Beverage Industries & 24 & 2 & 4 & 0 & 4 & 3 \\
\hline 22 & Tobacco Manufacturing & 5 & 0 & 2 & 0 & 0 & 0 \\
\hline 23 & Manufacturing of Textiles & 56 & 1 & 2 & 1 & 3 & 0 \\
\hline 24 & $\begin{array}{l}\text { Mfg of Footwear, } \\
\text { Clothing etc. }\end{array}$ & 133 & 9 & 5 & 2 & 2 & 2 \\
\hline 25 & $\begin{array}{l}\text { Manufacturing of } \\
\text { Wood \& Cork }\end{array}$ & 10 & 1 & 0 & 0 & 0 & 0 \\
\hline 26 & $\begin{array}{l}\text { Mfg of Furniture and } \\
\text { Fixtures }\end{array}$ & 672 & 57 & 20 & 9 & 2 & 1 \\
\hline 27 & Mfg of Paper Products & 18 & 2 & 1 & 2 & 1 & 1 \\
\hline 28 & Printing \& Allied Industries & 104 & 20 & 13 & 3 & 5 & 3 \\
\hline 29 & $\begin{array}{l}\text { Mfg of Leather \& } \\
\text { Leather Goods }\end{array}$ & 11 & 3 & 2 & 0 & 0 & 0 \\
\hline 30 & Mfg of Rubber Products & 11 & 0 & 1 & 0 & 0 & 1 \\
\hline 31 & Mfg of Chemical Products & 42 & 15 & 16 & 8 & 1 & 1 \\
\hline 32 & $\begin{array}{l}\text { Mfg of petroleum \& } \\
\text { coal products }\end{array}$ & 3 & 0 & 0 & 0 & 0 & 0 \\
\hline 33 & $\begin{array}{l}\text { Mfg of Non-Metallic } \\
\text { Products } \\
\text { (except petroleum and coal) }\end{array}$ & 210 & 21 & 12 & 4 & 5 & 1 \\
\hline 35 & $\begin{array}{l}\text { Manufacturing of } \\
\text { Metal Products }\end{array}$ & 306 & 40 & 16 & 6 & 3 & 1 \\
\hline 36 & Manufacturing of Machinery & 38 & 11 & 5 & 2 & 2 & 1 \\
\hline 37 & $\begin{array}{l}\text { Mfg of Electrical Machinery, } \\
\text { Appliances and Supplies }\end{array}$ & 287 & 42 & 20 & 5 & 7 & 2 \\
\hline 38 & $\begin{array}{l}\text { Mfg of Transport } \\
\text { Equipment } \\
\text { (excluding Malta Shipyards) }\end{array}$ & 689 & 36 & 15 & 5 & 2 & 4 \\
\hline 39 & $\begin{array}{l}\text { Miscellaneous Mfg } \\
\text { Industries }\end{array}$ & 167 & 24 & 17 & 8 & 8 & 2 \\
\hline 40 & Construction & 2356 & 83 & 54 & 17 & 14 & 4 \\
\hline 51 & Electricity \& Gas & 0 & 0 & 0 & 0 & 0 & 0 \\
\hline 61 & Wholesale and Retail Trades & 5671 & 312 & 176 & 47 & 36 & 11 \\
\hline 62 & $\begin{array}{l}\text { Banks \& Financial } \\
\text { Institutions }\end{array}$ & 15 & 11 & 0 & 3 & 2 & 1 \\
\hline 63 & Insurance & 69 & 11 & 11 & 4 & 4 & 2 \\
\hline 64 & Real Estate & 226 & 13 & 5 & 0 & 1 & 0 \\
\hline 71 & Transport & 1508 & 111 & 39 & 24 & 18 & 5 \\
\hline
\end{tabular}




\begin{tabular}{|c|c|c|c|c|c|c|}
\hline $75-99$ & $100-199$ & 200-399 & $400-499$ & $500-999$ & $1000+$ & Total \\
\hline 0 & 0 & 0 & 0 & 0 & 0 & 1415 \\
\hline 0 & 0 & 0 & 0 & 0 & 0 & 372 \\
\hline 1 & 0 & 0 & 0 & 0 & 0 & 95 \\
\hline 0 & 0 & 0 & 0 & 0 & 0 & 68 \\
\hline 0 & 0 & 0 & 0 & 0 & 0 & 1 \\
\hline 1 & 4 & 1 & 0 & 0 & 0 & 649 \\
\hline 1 & 1 & 0 & 1 & 0 & 0 & 40 \\
\hline 0 & 1 & 0 & 0 & 0 & 0 & 8 \\
\hline 0 & 0 & 2 & 0 & 1 & 0 & 66 \\
\hline 0 & 0 & 2 & 0 & 1 & 0 & 156 \\
\hline 0 & 0 & 0 & 0 & 0 & 0 & 11 \\
\hline 2 & 0 & 0 & 0 & 0 & 0 & 763 \\
\hline 1 & 0 & 0 & 0 & 0 & 0 & 26 \\
\hline 0 & 2 & 0 & 1 & 0 & 0 & 151 \\
\hline 0 & 1 & 0 & 0 & 0 & 0 & 17 \\
\hline 0 & 1 & 0 & 0 & 1 & 0 & 15 \\
\hline 0 & 0 & 1 & 0 & 0 & 0 & 84 \\
\hline 0 & 0 & 0 & 0 & 0 & 0 & 3 \\
\hline 1 & 0 & 0 & 0 & 0 & 0 & 254 \\
\hline 0 & 1 & 0 & 0 & 0 & 0 & 373 \\
\hline 0 & 0 & 1 & 0 & 0 & 0 & 60 \\
\hline 2 & 5 & 1 & 0 & 1 & 1 & 373 \\
\hline 2 & 1 & 0 & 0 & 0 & 1 & 755 \\
\hline 1 & 2 & 1 & 0 & 2 & 0 & 232 \\
\hline 0 & 5 & 2 & 0 & 0 & 0 & 2535 \\
\hline 0 & 0 & 0 & 0 & 0 & 1 & 1 \\
\hline 5 & 7 & 1 & 0 & 0 & 0 & 6266 \\
\hline 2 & 2 & 2 & 0 & 0 & 2 & 40 \\
\hline 2 & 0 & 0 & 0 & 0 & 0 & 103 \\
\hline 0 & 0 & 0 & 0 & 0 & 0 & 245 \\
\hline 3 & 2 & 3 & 0 & 0 & 1 & 1714 \\
\hline
\end{tabular}


Table 25.3 (continued)

\begin{tabular}{lrrrrrr}
\hline Industry Sector & $1-4$ & $5-9$ & $10-19$ & $20-29$ & $30-49$ & $50-74$ \\
\hline 72 Storage and Warehousing & 3 & 1 & 3 & 2 & 2 & 0 \\
73 Communications & 39 & 7 & 6 & 1 & 5 & 0 \\
81 Government Services & 0 & 0 & 0 & 0 & 0 & 0 \\
$82 \quad$ Community and & 2904 & 263 & 132 & 43 & 42 & 26 \\
$\quad$ Business & 261 & 11 & 7 & 1 & 0 & 2 \\
$83 \quad$ Recreation Services & 1114 & 106 & 53 & 25 & 23 & 15 \\
$84 \quad$ Hotel \& Catering & & & & & & \\
$\quad$ Establishments & 1737 & 34 & 11 & 4 & 2 & 3 \\
$\quad$ Other personal services) & $\mathbf{2 1 1 4 6}$ & $\mathbf{1 3 1 3}$ & $\mathbf{6 8 9}$ & $\mathbf{2 3 5}$ & $\mathbf{2 1 0}$ & $\mathbf{9 6}$ \\
Total No. of Employers & & & & &
\end{tabular}

Note: Sectors 20 to 39 cover the manufacturing elements.

Source: Employment \& Training Corporation (ETC), Malta.

\section{'Export or perish'}

Successful island entrepreneurs quickly develop an appreciation of how crucial 'off island' sales are to preserve and grow their business. Tourism is one easy route; but exportation is another step. The identification of distributors, dealers or agents is a common strategy, with close communication with the entrepreneur. Once again, the approach is wary, in small steps. State support can facilitate participating in a trade fair, from where good contacts can start. The 'export' of workers (emigrants) can also be a major source of income and foreign exchange via remittances.

\section{Human resource strategies}

People are crucial resources, especially to small businesses. Family labour is one route, especially where technological inputs are not as challenging. In the case of hi-tech firms, however, the best choice is not usually a relative. The unitary, team-based, labour relations in a small firm are enhanced by operating in a unitary island framework. This solidifies bonding, reducing labour turnover; but it may also make it difficult to discharge longserving employees, or for discharged employees to avoid being black-listed. Any specific labour market segment will be tight, so workers will be hard to recruit, tempting to poach, would need to be trained in-house, would have limited options for alternative employment - unless they decide to become self-employed and compete with their former boss! It is vital to offer possibilities of professional development, including stints off-island.

The gender dimension: profiling successful men and women

There is a remarkable level of entrepreneurship by both men and women in the showcased island firms, even if men are often, and perhaps even expected to be, more in the public eye. Control is transferred to, or shared with, members of the immediate family in many cases. The presence of women at the helm is inspiring. Many businesses survive because of the complementarity of the founding partners, often a male-female combination. 


\begin{tabular}{lcccccr}
\hline $75-99$ & $100-199$ & $200-399$ & $400-499$ & $500-999$ & $1000+$ & Total \\
\hline 0 & 0 & 0 & 0 & 0 & 0 & $\mathbf{1 1}$ \\
1 & 1 & 2 & 0 & 0 & 1 & $\mathbf{6 3}$ \\
0 & 0 & 0 & 0 & 0 & 1 & $\mathbf{1}$ \\
17 & 14 & 7 & 1 & 3 & 0 & $\mathbf{3 4 5 2}$ \\
0 & 2 & 0 & 0 & 0 & 0 & $\mathbf{2 8 4}$ \\
8 & 15 & 5 & 0 & 0 & 0 & $\mathbf{1 3 6 4}$ \\
1 & 0 & 0 & 0 & 0 & 0 & $\mathbf{1 7 9 2}$ \\
$\mathbf{5 1}$ & $\mathbf{6 7}$ & $\mathbf{3 1}$ & $\mathbf{3}$ & $\mathbf{9}$ & $\mathbf{8}$ & $\mathbf{2 3 8 5 8}$ \\
\hline
\end{tabular}

\section{Outside supports}

Small businesses from small islands tell different stories about external supports. Some are very enthusiastic, others disappointed; many are indifferent and frustrated by what they claim is 'red tape' and paperwork. Is a one-stop shop that difficult to set up? Why are island bureaucracies not exemplars of 'small is beautiful'? Or are island entrepreneurs simply suspicious of 'outsiders', whoever they might be? Government bureaucracy/regulations can strangle private enterprise: a judicious process of deregulation and liberalization can do wonders for promoting entrepreneurship and business. Appropriate forms of official assistance can be vital in such key areas as credit, training and marketing.

\section{Developing local expertise}

New technology can be adopted, adapted or invented outright. Successful small businesses excel at adaptation. The modification of an existing technology at a certain point becomes a new technique. Moreover, the disposition to become technologically innovative comes also from exposure to ideas and models developed off-island. Young islanders should be afforded the opportunity to travel off-island and spend time in metropolitan locations where ideas are generated.

\section{The link between the formal and informal sectors (including networks, politics and social capital)}

Social capital is very strong amongst small communities. Many small island entrepreneurs operate between the formal and informal sectors, as do many employees. Governments are often misled into believing that the informal sector acts to disguise productivity and therefore is a site of tax evasion which must be formalized and destroyed. The informal sector needs to be recognized as a strength and major support for entrepreneurial behaviour. Post-secondary and vocational training institutions require active and harmonious relations with nuggets of informal (but powerful) social capital, such as neighbourhood groups, cooperatives, voluntary associations and parish committees. 


\section{The effective teaching of entrepreneurship}

We end with a humbling note: only one of the entrepreneurial men and women showcased in the NISSOS case studies entered the world of business after following an entrepreneurial programme at school. This confirms that entrepreneurship is more likely to be developed out of school than in school. The question, therefore, naturally arises: is it a contradiction in terms to seek to foster entrepreneurship via the formal educational system? How innovative and formative can schools be in developing individuals keen to start their own businesses? Is a training manual on entrepreneurship a contradiction in terms?

\section{Policy implications}

These critical observations on the state of manufacturing in Malta can suggest lessons that can in turn inform local public policy. The following are some of the main implications of the above research outcomes to current Maltese economic development strategy.

First, is fostering networks of 'cooperative competition' in specific export industries, with local producers joining forces to defend the quality and reputation of their brand internationally, while continuing to compete amongst themselves locally. Some initiatives have been taken here, as in the case of jewelry manufacturers (for example, IPSE, 2001); these are now being championed by the Malta Crafts Council.

Second is the incorporation of institutes of technology and higher learning into drives towards the identification and promotion of entrepreneurship for example through such initiatives as Scoops: Coops for Schools, Young Enterprise and The President's Award, now all recognized in the National Minimum Curriculum. So far, it appears that entrepreneurship is negatively associated with graduate education in Malta (for example, Baldacchino et al., 1997).

Third is tapping into Malta's extensive overseas diaspora, with a view to attracting entrepreneurs to return to Malta and relocate their firms, or deploy their knowledge capital and extensive overseas networks in order to support local economic growth. Rather than a blanket sourcing drive, a more focused approach aimed at specific individuals may prove more successful. While Malta's 'geographical location, modern infrastructure, adequate and flexible labour supply and political stability are some of its key advantages' (Malta Enterprise web-site: www.maltaenterprise.com), when it comes to industrial investment, Maltese living abroad can be encouraged to return with the reassurance of a quality of life and strong social networks not easily experienced elsewhere.

Fourth is tourism, which is a crucial economic industry for Malta, but also crucial in the sense of facilitating the export of gourmet foods and wines and other choice hand-made craft products. Tourist purchases on the island relieve the producer of the responsibility for the transportation of goods overseas, with the accompanying surcharges for customs, insurance and freight, effectively off-loading these to a consenting customer.

\section{Conclusion}

Clearly, Malta's relatively low density of internationalized SMEs requires further investigation. The regulatory environment may be too stifling and bureaucratic. The Maltese may prefer low-risk investments, such as real estate, liquid bank deposits, government 
bonds and gold: a shrewd response bred during the feast and famine years of the fortress economy. The local corporate tax regime and the sprawling public sector may together disincentivize entrepreneurship and innovation, instead promoting and rewarding behavioural strategies that focus on how to 'work the system', or intrapreneurship: this includes 'safe' full-time public sector jobs and under-declared part-time incomes (see Delia, 1994). The informal economy persists as a haven for local business acumen (and in spite of the introduction of value added tax), perhaps because of what is widely perceived as a heavy corporate tax rate of 32.5 per cent. A pervasive belief that 'big is beautiful' may have led to the benign neglect of the potential of small, local firms to create employment, leading successive (especially Labour) governments to concentrate instead on attracting large, foreign companies to Malta (for example, Vella, 1994) or to set up large public corporations, resulting in a 'socialist black hole' of absent, stagnant enterprise (Vahčič and Petrin, 1990). Or is this an attitude problem, part of the legacy of industrial protectionism meant to defend nascent industries? Finally, is it simply that entrepreneurship in Malta enjoys very low social esteem, with small business owners being, by and large, still popularly regarded as primarily tax evaders? Malta's oldest profession remains, after all, piracy: and that speaks volumes.

\section{Acknowledgements}

This is a much expanded version of a paper published as: G. Baldacchino (2005) 'Successful small-scale manufacturing from Malta: a comparative assessment across five European island regions', Bank of Valletta Review (Malta), No. 31, pp. 17-32. The encouragement of Léo Dana and the constructive comments of anonymous reviewers have been especially welcome.

The support of the European Commission, through its Leonardo da Vinci Community Vocational Training Action Programme, in this ongoing pilot project - MT/2002/B/F/139000 - is gratefully acknowledged. My gratitude goes to the 11 institutional partners, their delegates and associated support staff involved in the NISSOS Project, for their support and commitment to the NISSOS Project's objectives. These are Estonia Chamber of Commerce and Industry - Saaremaa Branch (delegate: Tullio Liblik); Kuressaare College at Tallinn Technical University (Maret Pank and Merlin Muur); Åland Trade Association (Mika Lindfors and Johnny Mattson); Åland Polytechnic (Anna-Lena Sjöberg, Christer Kullman and Thor-Bjorn Wik); Technological Institute of Iceland (Bjorn Gislason); Institute of Business Studies at the University of Iceland (Gylfi Dalmann Adalsteinsson); Foundation for Human Resources Development, Malta (Sandra Agius, Helga Ellul, Mario Grixti, Godwin Micallef and John Muscat Drago); Malta Enterprise (Karl Herrera); the University of Malta (Roger Ellul Micallef and Saviour Rizzo); the Malta College for Arts, Science \& Technology (Frank Edwards); the Highland Council of Scotland (Catriona MacLean and Lisa Stephen) and the UHI Millennium Institute, Scotland (Maggie Marr, Anne Marie McDairmid and Stephanie Tristam). Thanks also to the expert independent input of Joe Vella Bonnici (Malta), Ingi Runar Edvardsson (Iceland) and Tage Petersen (Denmark). The institutional support of the University of Prince Edward Island, Canada, and the Employment \& Training Corporation (ETC), Malta, is also acknowledged. Responsibility for the contents of this chapter and any errors remain only my own, and are not attributable to either the European Commission or any of the NISSOS Project Partners.

(All Internet sites quoted in this chapter were accessed during July 2005.)

\section{Notes}

1. A case in point is the comparative study into SME performance undertaken by the Centre for Advanced Studies, Cardiff University, comparing firms in Denmark, Ireland and Wales (www.cf.ac.uk/cass/projects/ comparative_performance.html).

2. NISSOS (the Greek word for island) also stands for Network of Islands for Small Scale Organisational Success. The NISSOS Project is a three-year, pilot project under the European Commission's Leonardo da Vinci's Vocational Training Programme. It is coordinated by Malta Enterprise, and has 11 partners from five island regions of Europe: Åland, Iceland, Malta, Saaremaa (Estonia) and the Scottish Isles. Its website can be found at www.nissos.net.

3. Visit www.glass-time.com/Encyclopedia/Mdinaglass.html.

4. Visit www.shetland-knitwear.com/history.html. 
5. The University of Iceland (www.hi.is), Reykjavik University (www.ru.is) and the University of Akureyri (www.unak.is).

6. www.icetec.is/.

7. www.um.edu.mt; www.mcast.edu.mt, and www.maltaenterprise.com/page.asp?p=4078\&l=1 respectively.

8. http://eng.ttu.ee/structure/kuressaarecollege and www.ha.aland.fi/ respectively.

9. www.uhi.ac.uk/learningcentres/learning_centre.shtm\#mainland.

10. Just 33 out of 3952 manufacturing firms employing up to 50 persons in Malta in December 2004: data compiled and kindly made available by the Employment \& Training Corporation, Malta.

11. 'Liikanen proposes new perception of innovation', Cordis Newsletter, No. 195, Brussels, European Commission, April 2002, p. 1.

\section{References}

Alesina, Alberto and Enrico Spolaore (1997), 'On the number and size of nations', Quarterly Journal of Economics, 112(4), 1027-56.

Amin, Ash and Nigel Thrift (eds) (1994), Globalisation, Institutions and Regional Development in Europe, Oxford: Oxford University Press.

Armstrong, Harvey W. and Robert Read (2002), 'The phantom of liberty? Economic growth and the vulnerability of small states', Journal of International Development, 14(3), 435-58.

Armstrong, Harvey W. and Robert Read (2003), 'Small states, islands and small states that are also islands', Studies in Regional Science, 33(1), 237-60.

Baldacchino, Godfrey (1988), 'The industrialisation of Malta: a historical analysis of the formation, control and response of labour', in Ernest Azzopardi and Paul Heywood (eds), Issues: Aspects of an Island Economy, Malta: New Economics Society, pp. 60-87.

Baldacchino, Godfrey (1998a), 'Far better to serve in Heaven than to reign in Hell: Malta's logic of relating to the European Union', in Godfrey Baldacchino and Robert Greenwood (eds), Competing Strategies of Socioeconomic Development for Small Islands, Charlottetown, Canada: Institute of Island Studies, University of Prince Edward Island, pp. 213-37.

Baldacchino, Godfrey (1998b), 'The other way round: manufacturing as an extension of services in small island states', Asia Pacific Viewpoint, 39(3), 267-79.

Baldacchino, Godfrey (2002), 'A taste of small island success: a case from Prince Edward Island', Journal of Small Business Management, 40(3), 254-9.

Baldacchino, Godfrey (2004), 'The coming of age of island studies', Tijdschrift voor Economische en Sociale Geografie, 95(3), 272-84.

Baldacchino, Godfrey (2005a), 'Managing the hinterland beyond: two ideal-type strategies of economic development for small island territories', Asia-Pacific Viewpoint, (46), forthcoming.

Baldacchino, Godfrey (2005b), 'Successful small scale manufacturing from small islands: comparing firms benefiting from local raw material input', Journal of Small Business and Entrepreneurship, 18(1), 21-38.

Baldacchino, Godfrey (2005c), 'Island entrepreneurs: insights from exceptionally successful knowledge-driven SMEs from five European Island Territories', Journal of Enterprising Cultures, 13(2), forthcoming.

Baldacchino, Godfrey et al. (1997), The Graduating Workforce, Malta: Workers' Participation Development Centre for the Employment and Training Corporation.

Baldacchino, Godfrey and Joseph Vella Bonnici (2005), Real Stories of Small Business Success: Insights from Five European Island Regions: A Self-Help Guide, Malta: Malta Enterprise.

Barro, Robert J. and Xavier Sala-I-Martin (1995), Economic Growth, New York: McGraw-Hill.

Baum, Thomas G. with Laura Hagen-Grant, Lee Jolliffe, Sheldon Lambert and Bjorn Sigurjonsson (2000), 'Tourism', in Godfrey Baldacchino and David Milne (eds), Lessons in the Political Economy of Small Islands: The Resourcefulness of Jurisdiction, Basingstoke: Macmillan, pp. 214-30.

Bennell, Paul and John Oxenham (1983), 'Skills and qualifications for small island states', Labour and Society, 8(1), 3-38.

Biagini, Emilio and Brian Hoyle (eds) (1999), Insularity and Development: International Perspectives on Islands, London: Pinter.

Boissevain, Jeremy (1974), Friends of Friends: Networks, Manipulators and Coalitions, Oxford: Blackwell.

Boissevain, Jeremy (1991), 'Smallentrepreneurs and their cultural context', Bankof Valletta Review (Malta)(2), 1-16.

Boissevain, Jeremy et al. (1990), 'Ethnic entrepreneurs and ethnic strategies', in R. Waldinger, H. Aldrich, R. Ward et al. (eds), Ethnic Entrepreneurs: Immigrant Business in Industrial Societies, Newbury Park, CA: Sage, pp. 131-56.

Briguglio, Lino (1995), 'Small island developing states and their vulnerabilities', World Development, 23(9), $1615-32$.

Briguglio, Lino (1998), 'Surviving the competition: small business in Malta', in Godfrey Baldacchino and Robert Greenwood (eds), Competing Strategies of Socio-Economic Development for Small Islands, Charlottetown, Canada: Institute of Island Studies, University of Prince Edward Island, pp. 119-33. 
Brookfield, Harold C. (1987), 'Export or perish: commercial Agriculture in Fiji', in M.J. Taylor (ed.), Fiji: Future Imperfect?, Sydney: Allen and Unwin, pp. 46-57.

Busuttil, Salvino (1973), 'Malta's Economy in the Nineteenth Century', Department of Economics, University of Malta.

Commonwealth Secretariat (1997), A Future for Small States: Overcoming Vulnerability, London: Commonwealth Secretariat.

Coopers and Lybrand Europe (1991), The Effects of EC Membership on Industry in Malta, Malta: Malta Federation of Industry.

Delia, Emanuel P. (1994), 'A labour market in transition', in Ronald G. Sultana and Godfrey Baldacchino (eds), Maltese Society: A Sociological Inquiry. Malta: Mireva, pp. 461-81.

Easterly, William and Aart C. Kraay (2000), 'Small states, small problems: income, growth and volatility in small states', World Development, 28(11), 2013-27.

European Commission (1993), 'The challenge of enlargement: commission's opinion on Malta's application for membership', Bulletin of the European Communities, Supplement No. 4, Brussels, June.

Fairbairn, Teo I.J. (1988a), 'Indigenous entrepreneurship and business development in the Cook Islands', in Teo I.J. Fairbairn (ed.), Island Entrepreneurs: Problems and Performance in the South Pacific, Honolulu HI: East West Center, pp. 55-76.

Fairbairn, Teo I.J. (ed.) (1988b), Island Entrepreneurs: Problems and Performance in the South Pacific, Honolulu HI: East West Center.

Farrugia, Charles J. (1993), 'The special working environment of senior administrators in small states', World Development, 21(2), 221-6.

Golden, James R. (1994), Economics and National Strategy in the Information Age: Global Networks, Technology Policy and Cooperative Competition, Westport, CT: Praeger.

Granovetter, Marc (1984), 'Small is bountiful: labour markets and establishment size', American Sociological Review, 49(3), 323-34.

Institute for the Promotion of Small Enterprise (IPSE) (2001), Sectoral Analysis Report on the Jewelry Industry, Malta: Business Process Consulting for IPSE (available at www.maltaenterprise.com/filebank/documents/ Jewellery.pdf).

Jones, Oswald and Fiona Tilley (eds) (2003), Competitive Advantage in SMEs: Organizing for Innovation and Change, Chichester: John Wiley and Sons.

Kaminarides, John, Lino Briguglio and Henk Hoogendonk (eds) (1989), The Economic Development of Small Countries: Problems, Policies and Strategies, Delft: Eburon.

Liedholm, Carl and Donald C. Mead (1999), Small Enterprises and Economic Development, London: Routledge.

McClelland, David C. (1987), 'Characteristics of successful entrepreneurs', Journal of Creative Behaviour, 21(3), 219-33.

McDonald, Colin (1999), Small Enterprise Development in Mini Island Economies: The Case of Tobago, New York: Peter Lang.

Mizzi, Leonard (1996), 'Small and medium-scale enterprises in Malta and Cyprus', in Klitos Symeonides and Godfrey Baldacchino (eds), Cyprus and Malta on the Threshold of Accession to the European Union: Challenges to Workers and Trade Unions, Cyprus: Government Printer, pp. 12-18.

Porter, Michael (1990), The Competitive Advantage of Nations, New York: Free Press.

Royle, Stephen A. (2001), A Geography of Islands: Small Island Insularity, London: Routledge.

Seers, Dudley (1982), 'The new role of development planning', in Bimal Jalan (ed.), Problems and Policies in Small Economies, London: Croom Helm, pp. 69-84.

Sklair, Leslie (1993), Assembling for Development: The Maquila Industry in Mexico and the United States, University of California, San Diego: Center for U.S.-Mexican Studies.

Srebrnik, Henry F. (2000), 'Identity, culture and confidence in the global economy', in Godfrey Baldacchino and David Milne (eds), Lessons from the Political Economy of Small Islands: The Resourcefulness of Jurisdiction, Basingstoke: Macmillan, pp. 56-71.

Streeten, Paul P. (1993), 'The special problems of small countries', World Development, 21(2), 197-202.

Trevor-Roper, Hugh (1983), 'The invention of tradition: the highland tradition of Scotland', in Eric Hobsbawm and Terence Ranger (eds), The Invention of Tradition, Cambridge: Cambridge University Press, pp. $15-41$.

Urry, John (1990), The Tourist Gaze: Leisure and Travel in Contemporary Societies, London: Sage.

Vahčič, Aleš and Tea Petrin (1990), 'Restructuring the Yugoslav economy through the development of entrepreneurship and the role of the financial system', Slovene Studies, 12 (1), 67-73.

Vella, Mario (1994), 'That favourite dream of the colonies: industrialisation, dependence and development discourse in Malta', in Ronald G. Sultana and Godfrey Baldacchino (eds), Maltese Society: A Sociological Inquiry, Malta: Mireva, pp. 55-77.

Wignaraja, Ganeshan and Sue O’Neil (1999), SME Exports and Public Policies in Mauritius: 1999, Trade and Enterprise Papers, London: Commonwealth Secretariat. 


\section{Handbook of research on European business and entrepreneurship}

Zammit, Edward L. (1994), A Colonial Inheritance: Maltese Perceptions of Work, Power and Class Structure with Reference to the Labour Movement, Malta: Malta University Press.

Zammit, Edward L. and Yana Mintoff-Bland (1992), 'Workers' Participation in Technology and Production', Malta: Workers' Participation Development Centre, mimeograph. 